\title{
Presence of Granular Ducts in Mandibular Gland in Rabbit
}

\author{
Bianca MATOSZ ${ }^{1}$, Flavia RUXANDA ${ }^{1 *}$, Cristian RAŢIU ${ }^{2}$, Adrian Florin GAL ${ }^{1}$, Viorel MICLĂUŞ ${ }^{1}$ \\ ${ }^{1}$ Faculty of Veterinary Medicine, University of Agricultural Sciences and Veterinary Medicine Cluj- \\ Napoca, Romania. \\ ${ }^{2}$ Faculty of Medicine and Pharmacy, University of Oradea, Romania. \\ *corresponding author: flavia.ruxanda@gmail.com
}

Bulletin UASVM Veterinary Medicine 74(1) / 2017,

Print ISSN 1843-5270; Electronic ISSN 1843-5378

DOI:10.15835/buasvmcn-vm: 12614

\begin{abstract}
The present study focuses on the intralobular ducts present in rabbit mandibular gland, from a histological and histochemical point of view. We harvested mandibular gland samples from five healthy male rabbits (Oryctolagus cuniculus), acquired from a private breeder in Cluj county. Samples were paraffin embedded and subsequently stained for histological investigation with hematoxylin-eosin. PAS and Alcian blue reactions were used for histochemical assessment. Results show that mandibular gland in rabbit contains one type of acini, namely serous. Concerning the intralobular ducts, there were three types identified: intercalated, granular and striated. Granules present in the cytoplasm of the cells lining the granular ducts appear acidophilic on hematoxylin-eosin staining procedure. Histochemically, granular cells present a moderately PAS positive material (meaning they secrete neutral mucosubstances) and negative staining to Alcian blue reaction (no acid and sulfated mucosubstances were detected). We highlighted the presence of granular ducts in rabbit mandibular gland, which synthesize neutral mucosubstances according to the histochemical reactions applied.
\end{abstract}

Keywords: granular ducts, histochemistry, mandibular, rabbit.

\section{INTRODUCTION}

Mandibular glands are lobulated paired glands, which comprise sustaining tissue and parenchyma (Wolfgang, 2003; Gartner and Hiatt, 2007). Histologically, mandibular glands are formed out of acinar cells and ductal system. Acini are different according to the species and type of consumed nourishment. Histology of the duct system of salivary glands in mammals differs depending on the species taken into study (Al-Abadi, 2011). In most of the species, this system is formed out of intercalated, striated and interlobular ducts (main excretory ducts). In some species, for example in mouse, rat and hamster, besides these ducts, there is an additional one present, with a particular structure, found between the intercalated and striated ducts, known as granular duct (Bacha and
Bacha, 2006; Lydiatt and Bucher, 2012; Treuting and Dintzis, 2012).

We did not encounter data in specialty literature concerning the presence of granular ducts in rabbit. Instead, we found authors stating that in rabbit mandibular gland there is a segment of the intercalated ducts containing granular cells with PAS positive and Alcian blue negative cytoplasm. In other words, these authors consider the segments of the duct containing granular cells as part of the short non-granulated intercalated ducts (Shackleford and Klapper, 1962) and not as a separate category of ducts.

In this context, we considered opportune to investigate the intralobular ducts in rabbit mandibular gland, from a histological and histochemical point of view, in order to verify if 


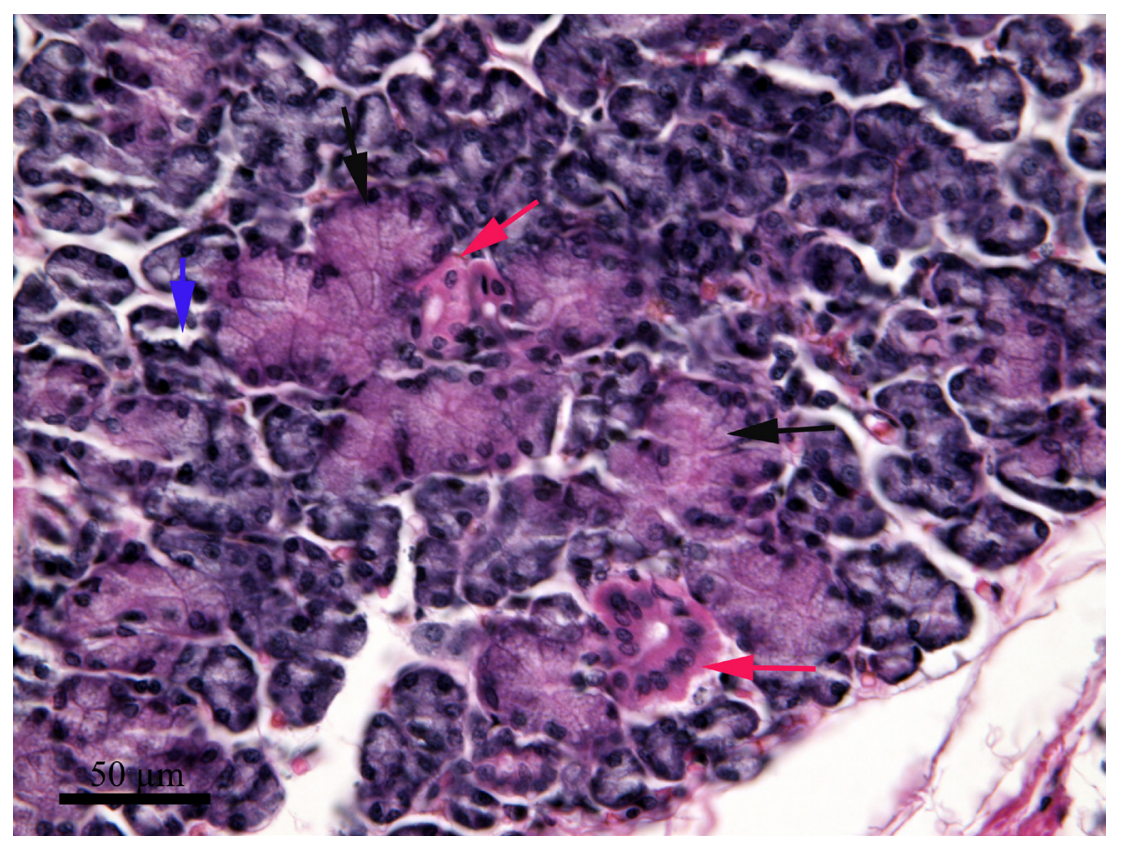

Fig. 1. Intralobular ducts: intercalated ducts (blue arrow); granular ducts (black arrows); striated ducts (red arrows) (H-E)

there are granular ducts present, which resemble the ones in rodents or only groups of granular cells in the walls of intercalated ducts.

\section{MATERIAL AND METHOD}

The biological material utilized in this study was represented by fivemalerabbits, approximately 6 months old, acquired from a private breeder in Cluj County, sacrificed by the breeder for own consumption. We harvested mandibular glands for histological and histochemical investigations. The samples were fixed in $10 \%$ buffered formalin, dehydrated in ethanol $\left(70^{\circ}, 95^{\circ}\right.$, absolute), clarified in n-buthanol and embedded in paraffin. We sectioned the sample in $5 \mu \mathrm{m}$ slices. The sections were stained with hematoxylin-eosin for histological investigation, while PAS reaction and Alcian blue were used for histochemical assessment (Kiernan, 1999). Histological and histochemical slides were examined under Olympus BX41 light microscope, endowed with a digital camera in order to capture images. Images were further processed with Adobe Photoshop CS2 software.

\section{RESULTS AND DISCUSSION}

In rabbit, the general aspect of mandibular gland is vastly similar to the one in rat and mouse, but notidentical. All acini are the same (concerning their type), presenting general characteristics of serous acini. There are three categories of ducts in mandibular gland from rabbit, one of them situated between the intercalated and striated ducts and resemble (but are not identical to) the granular ducts in rat (Fig. 1). These ducts are distributed throughout the whole surface of the lobule, and are well represented numerically (Fig. 2), but still seem to be less than the ones in rodents (mouse, rat etc.). Granules present in the cytoplasm of the cells lining these ducts appear acidophilic on hematoxylin-eosin staining procedure. Regarding their size, the granulations are polymorphic, with small and large sizes alike, comparable to the ones existent in rodent's mandibular gland (Fig. 3).

Granular ducts in rabbit mandibular gland are situated after intercalated ducts, which collect the secretion from acini (Fig. 4) and continue with striated ducts (Fig. 5).

In the cytoplasm of cells lining the granular ducts we highlighted moderately PAS positive material, which demonstrates that they secrete neutral mucosubstances (Fig. 6). Cytoplasm of acinar cells and those lining the striated ducts do not present PAS positive reaction, which demonstrates that they do not secrete neutral mucosubstances, at least not in quantities worth taking into consideration. 


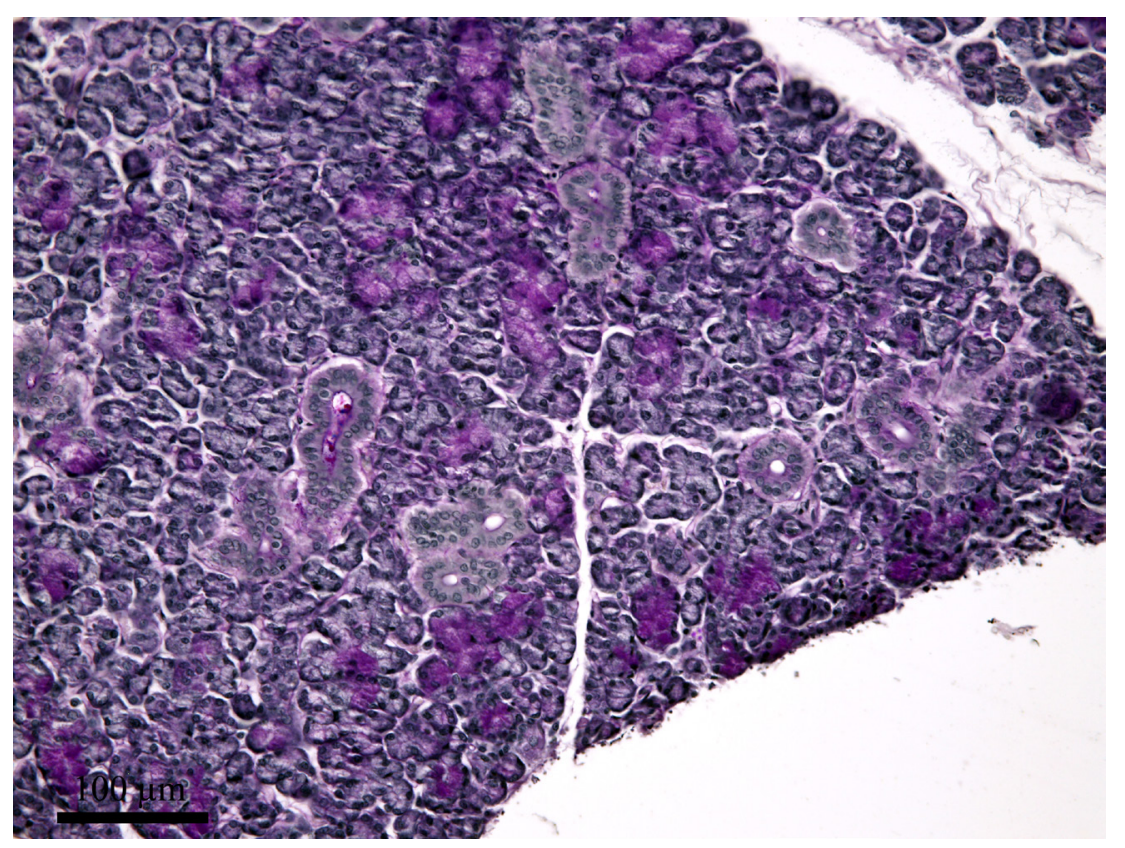

Fig. 2. Frequency and distribution of granular ducts (PAS)

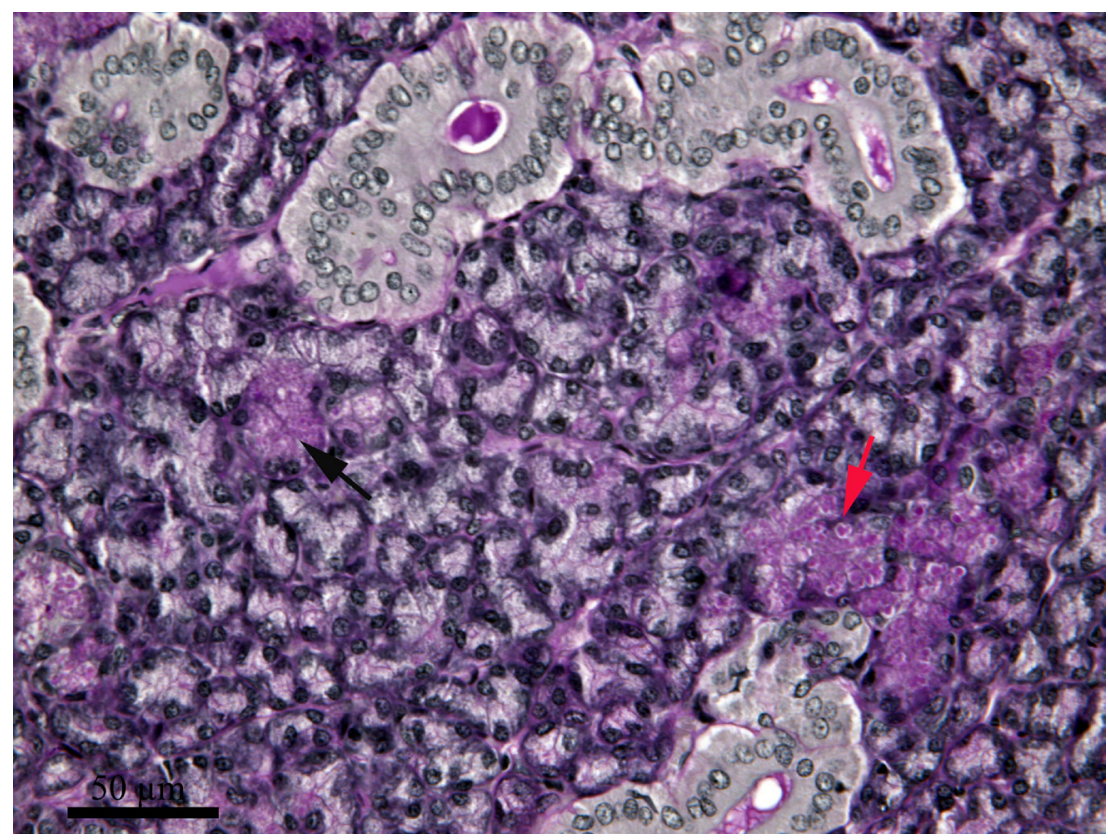

Fig. 3. Polymorphic granules in granular cells: small granules (black arrow); big granules (red arrow) (PAS)

After Alcian blue reaction, to detect acid and sulfated mucosubstances, results differed from the ones obtained after PAS reaction. Thus, acinar cells present positive reaction of medium intensity to Alcian blue, while those from granular ducts have negative reaction (Fig. 7).

Highlighting three types of intralobular excretory ducts, makes the rabbit mandibular gland resemble the one from rodents - which presents this structural particularity (mouse, rat, hamster) - from this point of view. Regarding their disposition, granular ducts from mandibular gland in rabbit are situated similarly to those in other species presenting granular ducts, namely between intercalated and striated ducts. The fact that granular cells from rabbit mandibular gland have secretory activity is suggested both by the shape of the cells (tall) and presence of 


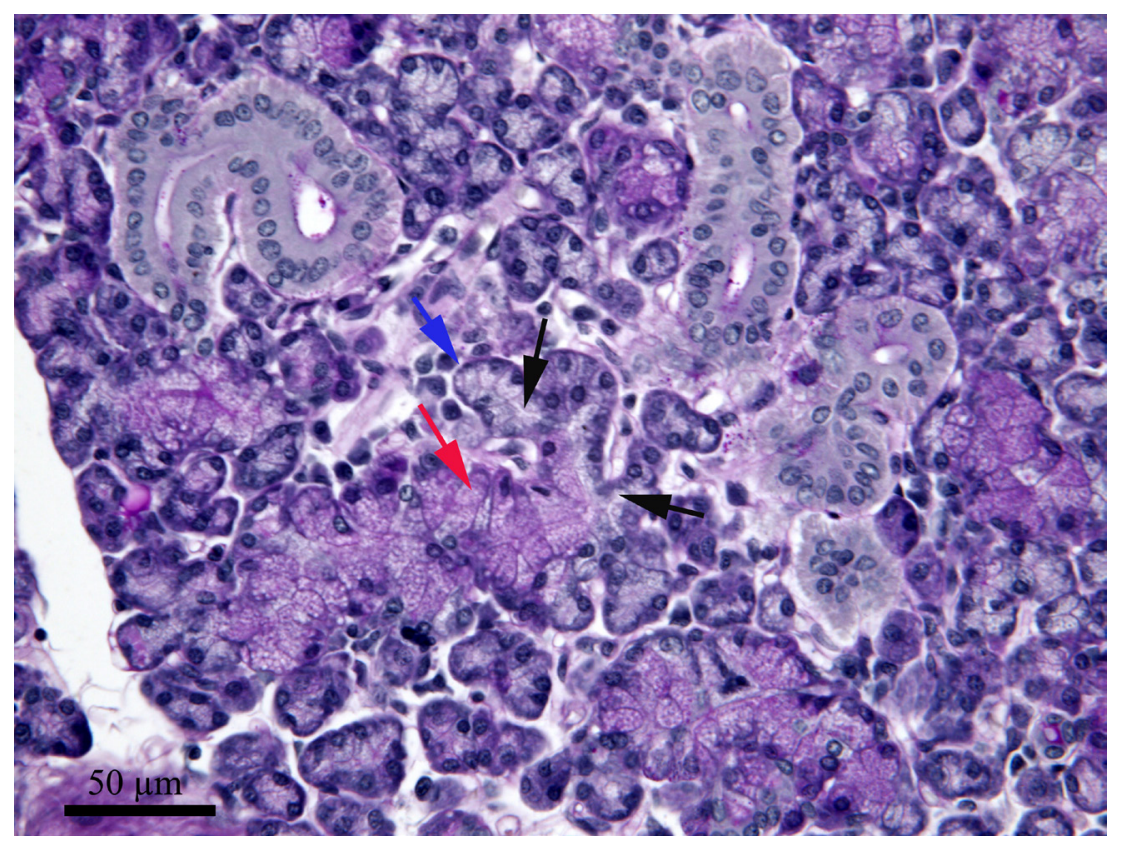

Fig. 4. Granular duct continuing the intercalated ducts: acinus (blue arrow); intercalated ducts (black arrows); granular duct (red arrow) (PAS)

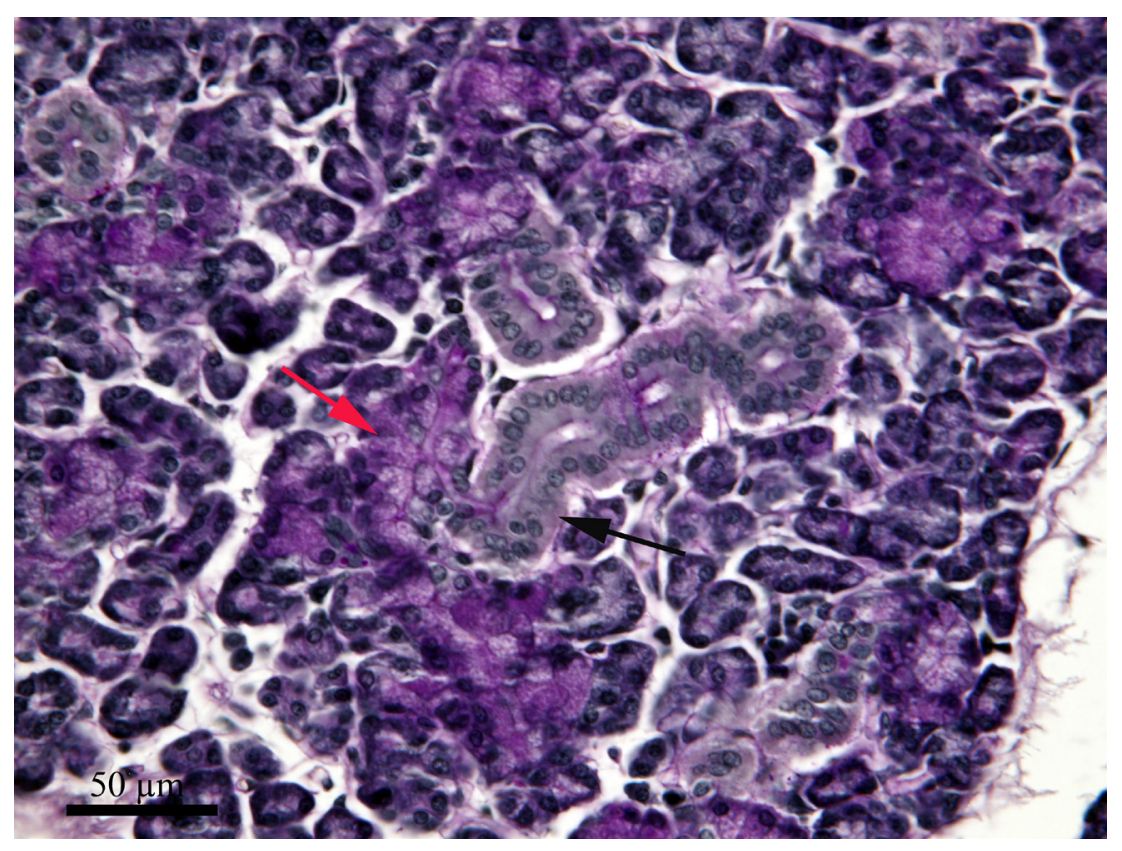

Fig. 5. Granular duct continuing with striated duct: granular duct (red arrow); striated duct (black arrow) (PAS)

polymorphic granulations containing secretion products in different maturation stages. Substances synthesized by cells in granular ducts' walls are different from those secreted in acinar cells. The affirmation is based on the fact that the substances contained in granulations are moderately PAS positive, while the cytoplasm of acinar cells is PAS negative, same as the one in striated ducts. These aspects suggest the fact that acinar cells do not secrete neutral mucosubstances, while those in granular ducts synthesize such substances. The fact that the secretion of granular ducts's cells is different from the one of acinar cells was also shown in the case of Alcian blue reaction, when the acinar cells were moderately positive, while cells in granular ducts' walls presented a negative 


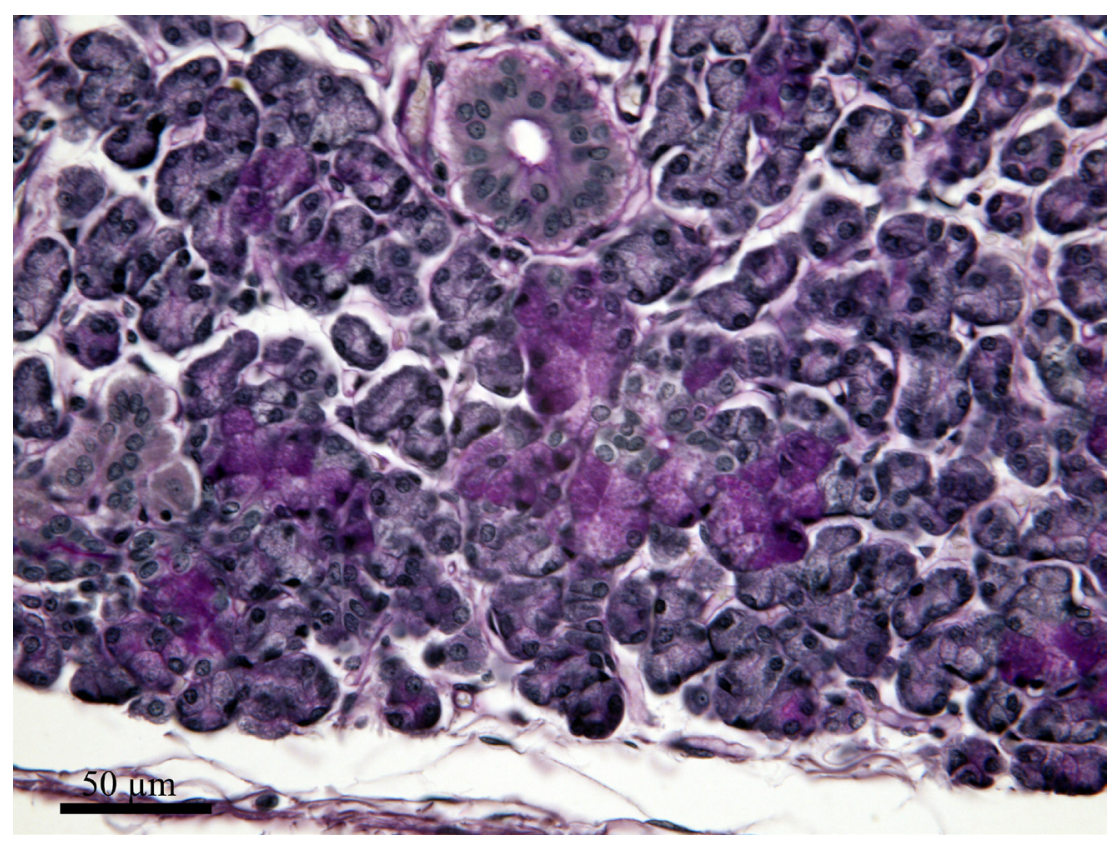

Fig. 6. PAS positive reaction in cells lining the granular ducts (PAS)

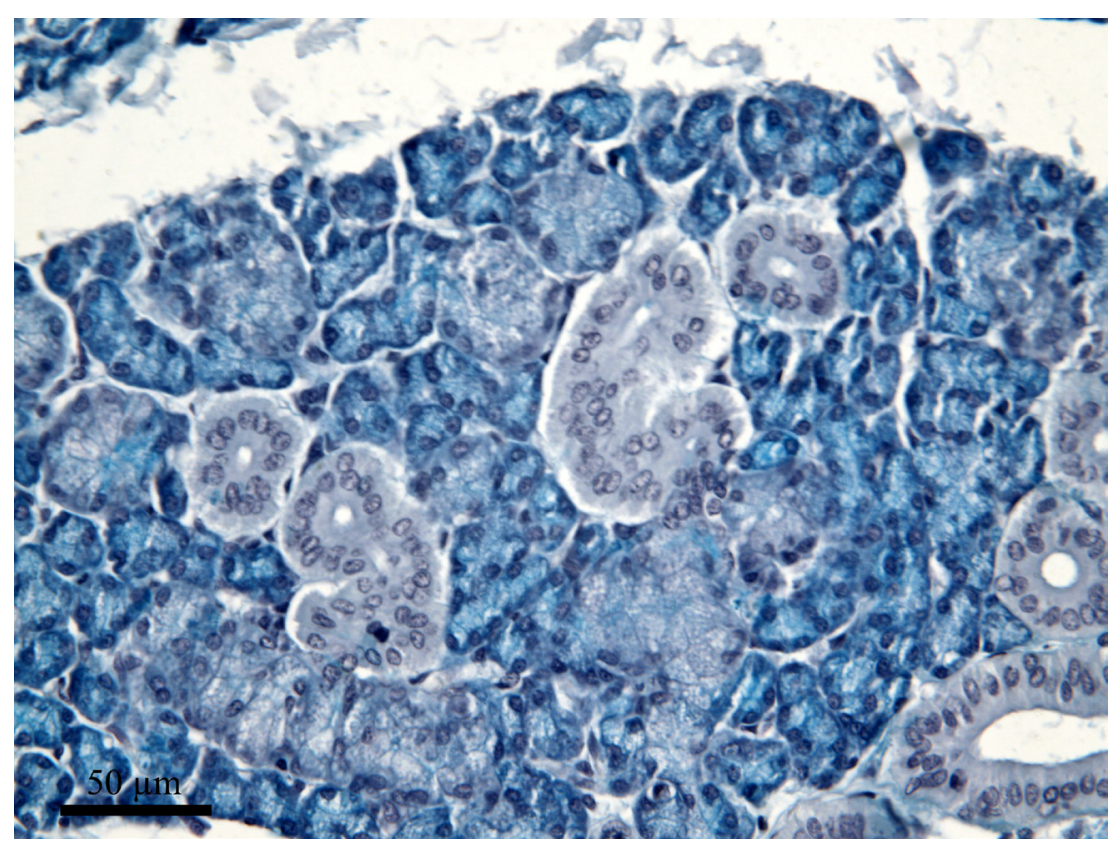

Fig. 7. Alcian blue negative reaction in cells lining the granular ducts (Alcian blue)

reaction. Alcian blue reaction results show the fact that acinar cells secrete acid mucosubstances in moderate quantities, while those in granular ducts secrete these kinds of mucosubstances in negligible quantities. Corroborating results from the two histochemical reactions, we can affirm that in rabbit mandibular gland, moderate quantities of both acid (acinar cells) and neutral (cells from granular ducts) mucosubstances are synthesized.
Results obtained in this study are not comparable to those in specialty literature, where there is no trenchant information on the granular ducts existence in rabbit mandibular gland. On the other hand, some authors affirm that there is a proximal granular segment of intercalated ducts which is PAS positive, but Alcian blue negative, in rabbit mandibular gland. Authors state that this granular segment continues with short non- 
granulated intercalated ducts (Shackleford and Klapper, 1962). In other words, these authors consider the segment of the duct with granular cells as a part of intercalated duct. The only resemblance of the results from these authors with the ones obtained by us referes to the fact that the cytoplasm of granular cells is PAS positive, but Alcian blue negative, similar to what we obtained. Other authors sustain that in rabbit mandibular gland there are three types of ducts: intercalated, striated (intralobular) and excretory (interlobular), same as in the majority of species, such as human (Al-Saffar and Simawy, 2014), ferret (Triantafyllou et al., 1999), miniatural pig (Xin et al., 2005), European hamster (Khojasteh and Delashoub, 2012). These authors did not highlight granular ducts in rabbit mandibular gland, nor segments of ducts with granular cells as previously mentioned authors. As opposed to these authors, we highlighted ducts with large numbers of granular cells, a situation comparable from many points of view to the one existent in animals which present four distinct segments for mandibular gland ducts: intercalated, granular, striated and excretory, as in gerbil (Bazan et al., 2001) or rodents (Tsuboi et al., 2004; Moghaddam et al., 2009).

\section{CONCLUSION}

Results obtained in this investigation demonstrate the existence of granular ducts in rabbit mandibular gland, with comparable aspect to those existent in some rodents, although in smaller numbers. Moreover, utilized histochemical reactions demonstrate the fact that cells from granular ducts in rabbit mandibular gland synthesize neutral mucosubstances.

\section{REFERENCES}

1. Al-Abadi MA (2011). Salivary gland cytology: A color atlas, Wiley-Blackwell, New Jersey.

2. Al-Saffar FJ, Simawy MSH (2014). Histomorphological and histochemical study of the major salivary glands of adult local rabbits, International Journal of Advanced Research 2(11):378-402.

3. Bacha WJ, Bacha LM (2006). Color atlas of veterinary histology. Second Edition, Blackwell Publishing.

4. Bazan E, Watanabe I, Iyomasa MM, Mizusaki CI, Sala M, Lopes RA (2001). Morphology Of The Submandibular Gland Of The Gerbil (Meriones Unguiculatus). A Macroscopic And Light Microscopy Study, Rev. chil. anat. vol.19 n.1.

5. Gartner LP, Hiatt JL (2007). Color Textbook of Histology, 3rd Edition, Saunders Elsevier.

6. Khojasteh SMB, Delashoub M (2012). Microscopic anatomy of the parotid and submandibular salivary glands in European hamster (Cricetus cricetus L.). Internat. Res. J. Appl. Basic Sci. 3(7): 1544-1548.

7. Kiernan JA (1999). Histological and histochemical methods: Theory and practice, Ed. 3, Butterworth Heinemann, Oxford, UK.

8. Lydiatt DD, Bucher GS (2012). The Historical Evolution of the Understanding of the Submandibular and Sublingual Salivary Glands. Clinical Anatomy 25:2-11, Wiley Periodicals, Inc.

9. Moghaddam FY, Darvish J, Mahdavi Shahri N, Abdulamir AS, Mousavi M, Daud SK (2009). Comparative histological and histochemical inter- species investigation of mammalian submandibular salivary glands. Res. J. Appl. Sci. 4(1): 50-56.

10. Shackleford J.M, Klapper CE (1962). Structure and Carbohydrate Histochemistry of Mammalian Salivary Glands. Am J Anat. 111:25-47.

11. Treuting PM, Dintzis S (2012). Comparative anatomy and histology. A mouse and human atlas, Academic Press, Washington.

12. Triantafyllou A, Fletcher D, Scott J (1999). Morphological phenotypes and functional capabilities of submandibular parenchymal cells of the ferret investigated by protein, mucosubstance and enzyme histochemistry. Histochem. J. 31:789-796.

13. Tsuboi T, Honda T, Hishida S, Shijetomi T, Ueda M, Sugiura Y (2004). A quantitative study of nerve fibers density in the submandibular gland of rats. Nagoya. J. Med. Sci. 67:25- 34 .

14. Wolfgang K (2003). Color Atlas of Cytology, Histology, and Microscopic Anatomy, Thieme Stuttgart, New York.

15. Xin Z, Jun L, Xiao-yong L, Yi-lin S, Chun-mei Z, Song-ling W (2005). Morphological characteristics of submandibular glands of miniature pig. Chin. Med. J. 118(16):1368- 1373. 